\title{
Impact of Micro Finance on Women Empowerment in Chittagong
}

\author{
Rajib Chakraborty ${ }^{1}$, C.V. Jayamani ${ }^{2}$ \\ ${ }^{1}$ School of Business Management and Legal Studies, University of Kerala,India \\ ${ }^{2}$ School of Management Studies, CUSAT, India
}

\begin{abstract}
In spite of some bottlenecks, Microfinance, a proven tool for empowering poor women by mitigating their extreme poverty to uplift them from vulnerable condition to some extent a better living atmosphere, has brought great changes in the women's living standard, has created an individual identity for the moderate poor women in the society and has given a freedom to live the life according to their choice. In this context this study makes a modest attempt to explore on the much debated question of the role of microfinance as a financial instrument for enhancing women empowerment through eradicating all financial and social obstacles. As a part of the study a primary field survey has been carried out to get a real picture in the rural area of the Chittagong district.

From the analyzed data the present study acknowledge that despite of bottlenecks, microfinance is capable of graduating struggling poor from their shackles and helps to upscale them to a better living and playing significantly positive role in upgrading women empowerment.
\end{abstract}

Keywords: Microfinance, women empowerment,

\section{Introduction}

By taking microfinance, an anti-poverty mechanism that encourages poor women to carry a good life and to make a sustainable financial condition as a part and parcel of their daily life, the world's poor women earlier who were financial excluded and had no recognition as earner for their family and also had been treated as character that always dominated by their male counterpart have obtained a position in their own society as empowered women by implementing their negotiating skill with their opposite sex with necessity and hard working mentality, dedication to their work , in born managerial power to make fit herself with the new atmosphere, where as a new comer having marriage adjusting with each member of the family and a universal law being a responsible mother, she is expected to take care her children at any cost along with her financial liability for betterment of the family.

Microfinance is the provision of financial services to low-income clients, including consumers and the self-employed, who traditionally lack access to banking and related services. Microcredit, or microfinance, is banking the unbankables bringing credit, savings and other essential financial services within the reach of millions of people who are too poor to be served by regular banks, in most cases because they are unable to offer sufficient collateral.

The main aim of microfinance is to empower women. Empowerment of women is a global challenge since traditionally women have been marginalized and subjected under the control of men. About 70 percent of world's poor are women (Khan \& Noreen, 2012). Traditionally, women especially those in underdeveloped countries have been unable to readily participate in economic activity. This social obstacle does not only impede women's integration in development but also make injustice towards women.

But when Bangladesh is concerned, a modern Muslim dominating country where poor women having some kind of religion restrictions especially in rural areas are much more empowered than women of other developing countries. Women in Bangladesh have gained an international reputation for their excellent performance as microfinance beneficiaries in microfinance institutions. For this in 2006 Grameen Bank, a well renowned microfinance institution and its founder Dr. Mohhamad Yunus have jointly been awarded Nobel Prize for peace. Some of the largest microfinance institutions of Bangladesh in the world -BRAC, Grameen Bank, ASA - provide access to finance to nearly 20 million poor people. With a population of 165 million of which 55 $\%$ are female and a density of 1127 person per square kilometer, Bangladesh is one of the most densely populated countries in the world. Poverty, landlessness, unemployment, malnutrition, rapid population growth and frequent natural disasters are the common endemic problems of the country. Apart from the problems, Bangladesh has some good news to discuss. Nobel laureate Professor Amarta Sen (2013) said "Immunization rates in Bangladesh are at 96 percent; Bangladesh comprehensively overtakes India in most human development categories except per capita income; I think women's agency made a big difference in Bangladesh.” Women got involved in family planning, immunization; health care early, those are helping Bangladesh to improve in some social indicators. 
Though so many research works have already been accomplished in microfinance and women empowerment field regarding Bangladesh but impact of microfinance on women empowerment in Chittagong is first initiative as per researcher's knowledge. The reason that encourages in selecting Chittagong as a research area is that Chittagong having the existence of a large number of international and national microfinance institutions working for more than three decades is the second largest division and commercial port city in of Bangladesh.

\subsection{Concept of Empowerment}

\section{Review Of Literature}

The notion of empowerment, propounded by Caroline Moser (1993), is focused on the individual -with control over resources seen as the central means for redistribution of power. Naila Kabeer (1994) implies that a "process by which those who have been denied the ability to make strategic life choices acquire such an ability, a feminist approach to power emphasizes transformative potential of power within which enables women to recognize and challenges gender inequality." In general empowerment refers to greater access to power by underprivileged or vulnerable segments of the population in the society. In its initial judicial meaning (Oxford Dictionary) to empower is to give somebody the power or authority to do something. According to Rowlands, empowerment is a process whereby women become able to organize themselves to increase their own selfreliance, to assert their independent right to make choices and to control resources which will assist in challenging and eliminating their own subordination"( 1997). The UNDP report of 1995 emphasized gender by introducing two new complementary indices: the Gender-related Development Index (GDI) and the Gender Empowerment Measure (GEM). Whereas the GDI employs the indicators that constitute the Human Development Index to measure the inequalities between men and women in terms of access to basic needs, the GEM evaluates women's access to political and economic posts. The UNDP, on the basis of the conceptual framework of Amartya Sen, establishes the following distinction concerning the range of the two indicators: "while the GDI focuses on the Extension of capabilities, the GEM is concerned with the use of those capabilities to take advantage of the opportunities of life" (Human Development Report of the UNDP 1995: 73). From the institutional view of Department for International Development (DFID), "women's empowerment is more than simply marginal increase in income -it requires a transformation of power relations... this means that development must take into account, not only income level but also relations within households, markets and communities, national and international economics".

\subsection{Women and Micro Finance}

Providing credit to poor women has been accepted as a means of economic development (Ackerly, 1995 ) and an effective means for empowering women (Bartlett,2004;Kay,2002).

It is believed that providing women with the proper resources, they have the power to help the whole family and entire communities escape poverty. Providing access to finance for entrepreneurial activities, microfinance services can significantly increased women ability and capacity to work independently which reduce their vulnerability to poverty (Wrigley-Asante 2011).

Many evaluations of MFIs have shown that microfinance services have a positive impact on women (Hashemi et al., 1996; Khandker, 2005; Lakwo, 2006).

Mahmud (2006) found that credit programs had significant effects on eight different dimensions of women's empowerment. He found that women's access to credit was significant determinant of the magnitude of economic contributions reported by women.

Pitt and Khandker (1998) found that program credit has a larger effect on the behavior of poor household in Bangladesh when women are the program participants. They also found that annual household consumption expenditure increases $\$ 0.22$ for every additional $\$ 1.22$ borrowed by women from credit programs, compared with $\$ 0.13$ for man.

In her study, Ackerly (1995) noted that underpinning most credit interventions in Bangladesh was an implicit model of the empowered woman: Empowered, the borrower wisely invests in a successful enterprise, her husband stops beating her, she sends her children to school, she improves the health and nutrition of her family, and she participates in major family decisions.

\section{Objectives Of The Study}

The specific objectives of this study are:

1. To study the background characteristics of the microfinance beneficiaries in Chittagong.

2. To examine the income level of the beneficiaries after joining microfinance institutions

3. To examine the impact of the microfinance on beneficiary's consciousness and decision-making power in the family.

4. To analyze the psychological and sociological empowerment of the women beneficiaries in Chittagong. 


\section{Sampling and Data Collection Method}

The study covers a sample size of 150.This study is undertaken in rural areas in Chittagong division where BRAC, an internationally reputed MFI, UDDIPON and ASA, the national level NGOs have been working for more than 10 years. Three (3) years regular membership with the status of "active female beneficiaries" is the basic criteria for selecting respondents as sample for the study. Since all MFIs have a large number of branches, three branches have been selected purposively. From each three branches, fifty (50) beneficiaries have been selected randomly. A structured interview schedule has been prepared for collecting primary data. To measure women empowerment, a series of questions has been developed encompassing a variety of aspects of women's economic condition, psychological strength, relative power, consciousness level and degree of autonomy about decision making power within the family through extensive literature review and interviews with respondents in research area and informal conversation with credit program staff. As part of the data analysis, statistical tools correlation, frequency distribution, ANOVA, have been applied.

\section{Limitations Of The Study}

1. The study is confined with the rural areas of Chittagong. Hence the results may not be applicable to urban areas of Chittagong.

2. The data was collected only from those who engaged in income generating activities for more than three years.

3. As the respondents' education level is not up to the mark to understand the meaning of psychological empowerment and the decision making role, sometimes they have faced difficulties to answers.

3. Due to time constraint and financial limitations, 150 respondents have been selected. Thus the findings of this study may not be suitable for making generalization to the other same or related field studies.

\section{Background Characteristics Of The Female Beneficiaries}

This section will examine the background of the female loanees with a view to describe the personal qualifications like educational attainment, marital status, age, family background, monthly income etc.

Table 1 gives age distribution of female beneficiaries. It is seen that the female loanees are more concentrated among the middle age group. Having $5.3 \%$ beneficiaries in the total sample respondents, the participation of the eldest group is least.

TABLE 1

Distribution of beneficiaries by Age and Sex

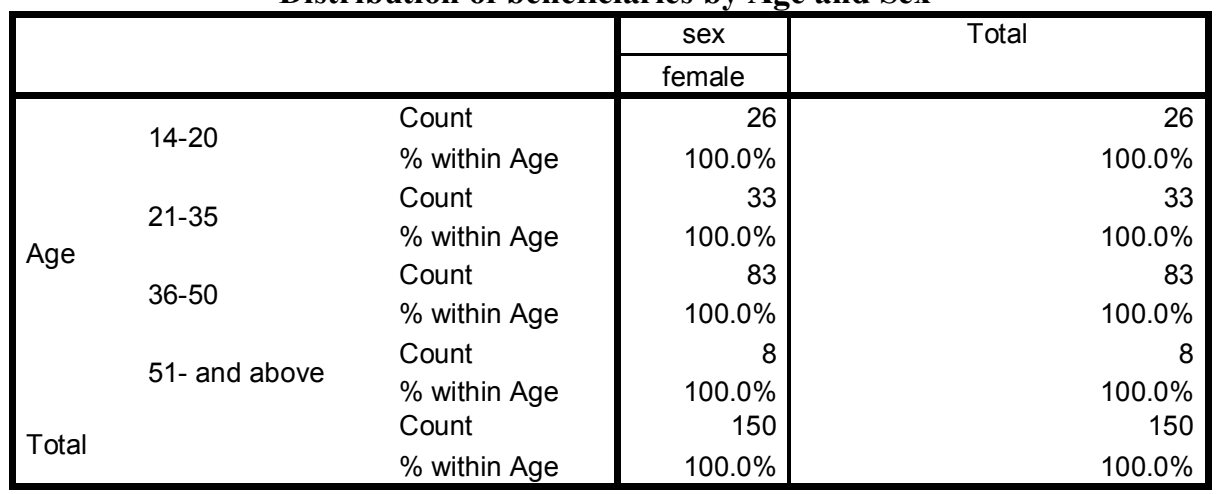

TABLE 2

Distribution of beneficiaries by Age and duration of membership

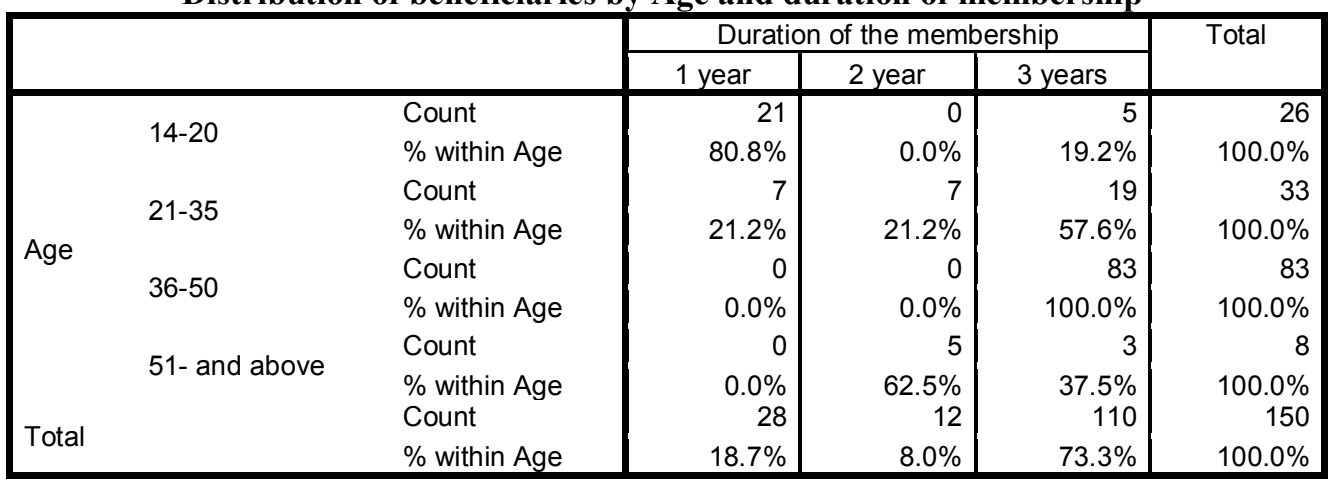


It is clear from the table 2 that women who have been joined microfinance institutions for longer period are in the 36-50 age group. The positive side for the Bangladeshi women is that the younger group is also more interested to join microfinance institutions to change their life. This would support the contention that now the younger generation are likely to be more free from norms of purdah or nekab .

TABLE 3

Distribution of beneficiaries by Marital status and duration of the membership

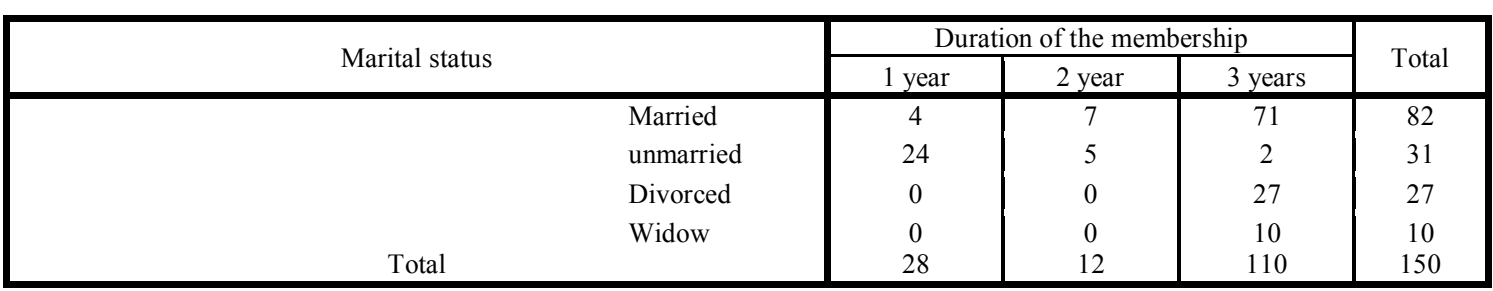

Source: field survey

It is evident from table 3 that $54 \%$ respondents of the total sample size are married and the next place is occupied by the unmarried women. But a significant number of divorced and widows women who form a special disadvantaged group in the society having some degree of freedom in taking their own decision are also beneficiaries of the microfinance institutions. It is well known that the religion norms sometimes pressurize unmarried women to avoid the male dominated social gatherings and to restrain them to participate in work outside home but according to the above data, the married women as beneficiaries have been able to overcome the same problem. Again if we look at the marital status of women by their period of membership, we find that even among the older members more than $55 \%$ are married. Thus, marriage is not a barrier to join microfinance institutions.

TABLE 4

Distribution of beneficiaries by Marital status and duration of the membership

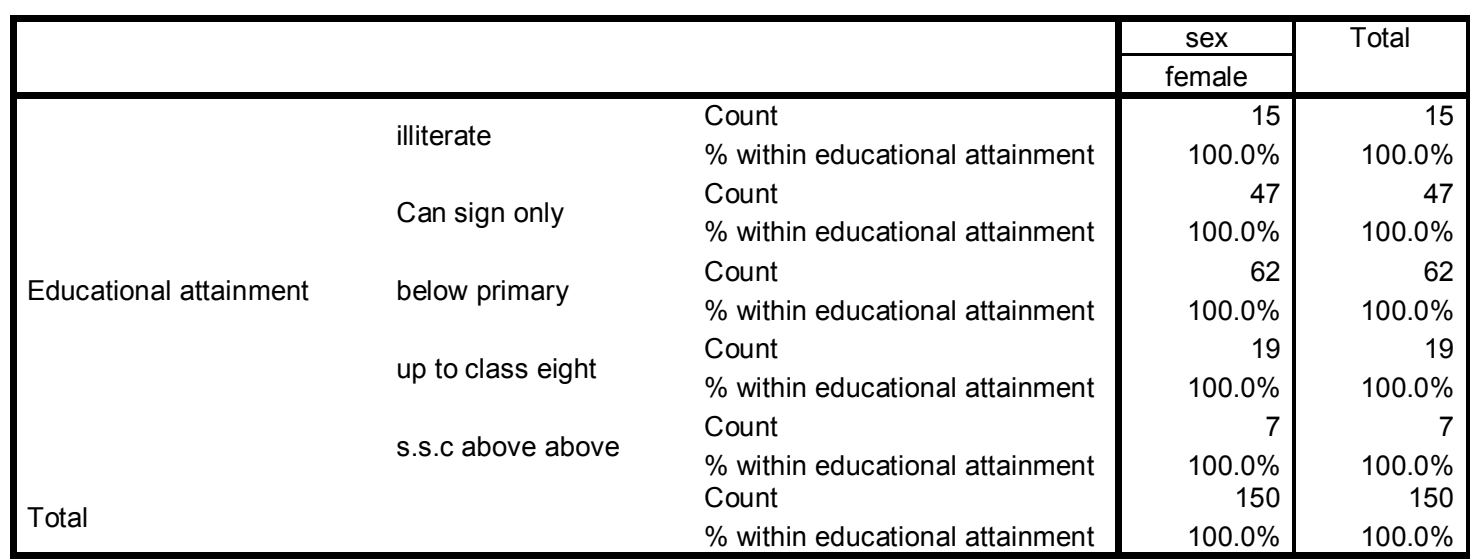

Table 5 shows that $20 \%$ respondents have taken above primary or higher level education. More than $80 \%$ beneficiaries education level are up to the below primary level. Thus education does not seem to be a necessary prerequisite to act as a driving force to join microfinance institutions.

TABLE 5

Change in income of beneficiaries before and after joining Micro finance

\begin{tabular}{|c|c|c|c|c|}
\hline Income & Mean & N & Std. Deviation & Std. Error Mean \\
\hline before & 3380.0000 & 150 & 428.35725 & 34.97522 \\
\hline after & 3970.0000 & 150 & 348.67920 & 28.46954 \\
\hline
\end{tabular}

Source: Field survey

t -10.773.,df 149., p .000* 
Table 5 shows change in income after joining the group. The analysis shows that there is an increase in the income of beneficiaries. Paired $t$ test has been conducted to test the statistical validity of the change and the $p$ value shows that the $t$ value is significant.

TABLE 6

ANOVA between savings, borrowings and bargaining power

\begin{tabular}{|l|l|l|l|l|}
\hline & Sum of Squares & Df & Mean Square & F \\
\hline Between Groups & 442.13 & 2 & 221.07 & 18.53 \\
Within Groups & 143.13 & 12 & 11.93 & \\
Total & 585.33 & 14 & & \\
\hline
\end{tabular}

As calculated value of ANOVA (18.53) is greater than the table value (3.886) at $5 \%$ level of significance, So null hypothesis is rejected. It is concluded that savings as well as borrowing increases the bargaining power of the female beneficiaries.

TABLE 7

Correlations between recognition of women's contribution and positive changes on gender norms

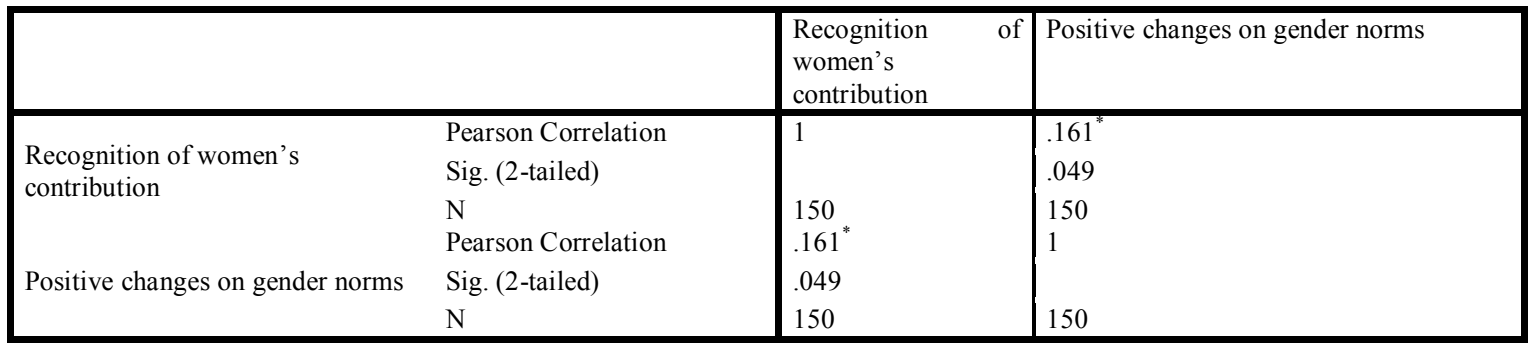

Source : Field survey

*. Correlation is significant at the 0.05 level (2-tailed).

It is evident from the table 7 that there is a significant correlation between recognition of women's contribution to the family and positive changes on gender norms.

TABLE 8

Percentage distribution of psychological variables for Divorce women

\begin{tabular}{|l|c|c|c|c|c|}
\hline Variables & Yes & $\%$ & No & $\%$ & Total \\
\hline Self Confidence & 24 & 88.88 & 3 & 11 & 27 \\
\hline Mental Strength & 22 & 81.48 & 5 & 18 & 27 \\
\hline Sense of future planning & 21 & 77.77 & 6 & 22 & 27 \\
\hline Bargaining power & 26 & 96.29 & 1 & 4 & 27 \\
\hline Political awareness & 19 & 70.37 & 8 & 29 & 27 \\
\hline
\end{tabular}

Source: Field survey

From the table 8 it is palpable that sample representations of the divorce women having higher education level have high self confidence level and bargaining power. Since Bangladesh is a modern Islamic dominating country, female have some restrictions to freely express their opinion in public or within the family. But the microfinance beneficiaries have been capable of changing the situation in their locality. That's why having discontent in the family with their husbands; empowered women are sometimes forced or to some extent willingly they break up their conjugal life to live with respect. Here a noticeable thing from the collected data is that this group has a strong political awareness.

\section{Impact of Micro Finance on the Consciousness and Decision-Making Power of the} Women

Women's participation in the economic activity is not only for her financial solvency that labels herself as a key financial player for the overall effective growth Of the national economy but also is expected to have some secondary influences in the life and attitude of these women. As they are earner like their opposite sex, they have the responsibility to engage themselves in the decision-making activities in the family that will bring more fruitful result than earlier decision taken by one in the family. Though developing valid and reliable indicators of women's empowerment is one of the most difficult tasks, from extensive literature review following indicators have been developed for measuring women's decision-making capacity in the family. 
TABLE 9

Percentage of Beneficiaries where Decision is taken mainly by the Housewives or jointly by their Husbands or by others

\begin{tabular}{|c|c|c|c|c|c|c|}
\hline Variables & Self & $\%$ & Jointly & $\%$ & Others & $\%$ \\
\hline Day to day purchase & 23 & 28 & 50 & 61 & 10 & 12 \\
\hline On going to market & 16 & 19 & 60 & 73 & 7 & 85 \\
\hline Purchase of clothing & 11 & 13 & 55 & 67 & 17 & 21 \\
\hline Children age of marriage & 12 & 15 & 65 & 79 & 5 & 61 \\
\hline Travel to relatives house & 20 & 24 & 52 & 64 & 10 & 12 \\
\hline
\end{tabular}

Source: Field survey

Table 9 shows that in all spheres of the decision-making for all variables, more than 60 percent female beneficiaries have a strong participation in the decision-making with 15 percent women having individual decision in the family ensured/ensuring the $2^{\text {nd }}$ position.

Now let us see having control in the decision-making activities in family matters, how much the female beneficiaries utilize their knowledge to make them aware about a few important indicators regarding consciousness.

TABLE 10

Percentage Distribution of Consciousness level for Female Beneficiaries

\begin{tabular}{|l|c|c|c|c|c|}
\hline Variables & Yes & $\%$ & No & $\%$ & Total \\
\hline Exercising voting right in last election & 100 & 74 & 35 & 26 & 135 \\
\hline Using contraceptive & 80 & 60 & 55 & 40 & 135 \\
\hline Using tube well for drinking & 95 & 70 & 40 & 30 & 135 \\
\hline Knowing method of preparing oral saline & 120 & 89 & 15 & 11 & 135 \\
\hline
\end{tabular}

Source: Field survey

It is noticeable from the table 9 that more than 70 percent beneficiaries are aware of preparing oral saline while 100 beneficiaries from 135 adult respondents having a voting right exercised their voting right in the last union election. With respect to drink safe water, the percentage of using tube well for drinking water is satisfactory along with 70 percent respondents using contraceptive.

TABLE 11

Percentage Distribution of Psychological variables for Microfinance Beneficiaries

\begin{tabular}{|l|c|c|c|c|c|}
\hline Variables & Yes & $\%$ & No & $\%$ & Total \\
\hline Self Confidence & 136 & 90.7 & 14 & 9.3 & 150 \\
\hline Mental Strength & 125 & 83.4 & 15 & 16.6 & 150 \\
\hline Sense of future planning & 105 & 70 & 45 & 30 & 150 \\
\hline Awareness in child education & 101 & 67.33 & 49 & 32.67 & 150 \\
\hline Self reliance & 120 & 80 & 30 & 20 & 150 \\
\hline Sense of security & 109 & 72.66 & 41 & 27.34 & 150 \\
\hline Improvement in health care & 106 & 70.66 & 44 & 29.24 & 150 \\
\hline
\end{tabular}

Source : Field survey

From the table 11, It is found that highest 90 percent beneficiaries have been self-confident while 83 percent have the mental strength. In respect of future planning and awareness in child education, beneficiaries' responses are less than 70 percent.

\section{Findings}

1. At first from the above analysis it is proved that the microfinance beneficiaries specially the targeted women have been encouraged a lot by the microfinance institutions working in the research area through the MFI's innovative approach to motivate the rural backward women who had earlier nothing or had no courage to change their life style to make them economically to some extent solvent, self-confident.

2. It is found that the beneficiaries have expressed their satisfaction in respect of their income that increased and changed financial condition in the family level after joining microfinance institutions.

3. It is also mentioned that a significant percentage of respondents are psychologically developed by giving the "yes" answers to the variables developed for measuring the psychological empowerment.

4. Most of the beneficiaries who participated as sample respondents for this study have strong participation in the decision-making in the families evaluate female beneficiaries as member like their male members that was rarely happened earlier.

5. As a densely populated country in the world where 80 percent people having minimum education level live in village, microfinance institutions have made a good attempt to make them conscious to use tube well water for drinking and contraceptive for avoiding unplanned extended family. 
6. From the correlation, we can articulate that recognition of the women's dedication/battle for the improvement of family's economic condition from their male dominated family is an affirmative sign to bring positive changes on gender norms, the practice that will make a wider impact on community and country.

7. Statistical ANOVA analysis has inveterate that capacity of savings and borrowings increases bargaining power of the beneficiaries.

\section{Conclusion}

Microfinance, a poverty alleviation tool to mitigate the vulnerability of the people of the weaker section in the society, has widely been implementing all over the world by engaging especially, the women in the main stream economic development. From the conducted study suggests that microfinance has been able to make poor women psychologically empowered and has raised their consciousness level high. It is also found that now they are equally capable of executing their decision- making power in the family matters. From the table of consciousness level of the beneficiaries, it is evident that the consciousness level regarding exercising voting right, preparing oral saline and drinking tube well water is satisfactory while the habit of using contraceptive is little bit low.

Thus for the overall development of the country including rural sector, the weaker section women must be included as the key force with the existing male dominated financial sectors and all the development program must be addressed to the financially backward women .

\section{References}

[1]. Sarumathi. S.,Mohan.k, Role of micro finance in women's empowerment -An Empirical study in Pondicherry region rural SHG's; Journal of Management and Science Vol.1, No.1 (Sep'2011) ISSN: 2249-12

[2]. Klara Haugen-Kossmann; "Micro-Finance and Empowerment From a Woman's Perspective" Copenhagen Business School, October 2008

[3]. Ramu Maurya; “Women , Micro finance and financial inclusion in india”; International journal of business economics and management research Volume 2, Issue 7 (July, 2011) ISSN 2229-4848

[4]. Farhad Hossain Tonya Knight, Financing the Poor: Can microcredit make a difference? Empirical observations from Bangladesh" February 2008 BWPI Working Paper 38

[5]. Manjula Bolthajjira Chengappa. "Micro-Finance and Women Empowerment: Role of Nongovernment Organizations". http://www.istr.org/Abstracts2010/pdf/ISTR2010_0212.pdf.

[6]. Goetz, Anne Marrie,and Rina Sen Gupta.1996. Who takes the credit? Gender, power and control over loan use in rural credit programs in Bangladesh. World Development, 24 (1), 45-63.

[7]. Kabeer, Naila.2005. Is microfinance a magic bullet for women empowerment? Analysis of South Asia, Economic and Political Weekly, 40(44), 4709-4718.

[8]. Kan, Jainaba M.L., Dana .L .Olds, and Muhammadou. M. O Kah. 2005. Microcredit, social Capital and politics. Journal of Microfinance, 7 (1), 121.

[9]. Rahman, R. I., 2002. "Impact of Grameen Bank on the Situation of Rural Women" Early Impact of Grameen: A multi-Dimentional Analysis: Outcome of a BIDS Research Study. Grameen Trust, Dhaka.

[10]. Ackerly, B. A. (1995). Testing the tools of development: credit programs, loan involvement and women's empowerment. IDS Bulletin, 26(3), 56-68. 